\title{
The Effect of Lysimachia savranii on the Breast Cancer Cells in Cell Culture Conditions Compared to Normal Cells
}

\author{
Lysimachia Savranii'nin Hücre Kültürü Ortamında Normal Hücrelere Göre Meme Kanseri Hücrelerine Etkisi
}

\author{
Iş1 AYDEMİR ${ }^{*(D)}$, Caner ÖZBEY² (iD), Gonca DÖNMEZ ARAT ${ }^{3}$ (D), Oktay ÖZKAN ${ }^{4}$ (D), Ahmet \\ SAVRAN5 ${ }^{(D)}$, Sevinç İNAN6 (i), Mehmet İbrahim TUĞLU7 ${ }^{(1 D)}$ \\ ${ }^{1}$ Nigde Ömer Halisdemir University, Faculty of Medicine, Department of Histology and Embryology, Nigde, Turkey \\ ${ }^{2}$ Nigde Ömer Halisdemir University, Faculty of Medicine, Department of Pathology, Nigde, Turkey \\ ${ }^{3}$ Nigde Ömer Halisdemir University, Faculty of Medicine, Department of Medicinal Biology, Nigde, Turkey \\ ${ }^{4}$ Nigde Ömer Halisdemir University, Faculty of Medicine, Department of Medicinal Pharmacology Nigde, Turkey \\ ${ }^{5}$ Nigde Ömer Halisdemir University, Faculty of Arts and Sciences, Department of Biology, Nigde, Turkey \\ ${ }^{6}$ Izmir University of Economics, Faculty of Medicine, Department of Histology and Embryology, İzmir, Turkey \\ ${ }^{7}$ Manisa Celal Bayar University, Faculty of Medicine, Department of Histology and Embryology, Manisa, Turkey
}

\begin{abstract}
The breast cancer has become a threat to women's lives at an increasing rate. The inadequate treatments of surgical procedures and chemotherapy affect negatively the quality of patient life. Therefore, there has been an increase in demand for alternative and supportive agents, especially for the use of herbal products. The purpose of this study is to evaluate the in vitro anti-tumor activity of Lysimachia savranii in breast cancer cell lines compared to normal adipose tissue derived mesenchymal stem cells. The adipose tissue derived mesenchymal stem cells as normal cells with MCF-7 and, MDA-MB-231 breast cancer cells were cultured. IC $_{50}$ doses of Lysimachia savranii extract for each cells were determined via 3-(4, 5-dimethylthiazolyl-2)-2, 5-diphenyltetrazolium bromide (MTT) assay. The immunocytochemical staining was performed for the oxidative stress by eNOS, whereas apoptosis were analyzed by TUNEL method. The data exhibited with H-score and apoptotic index. The plant extract inhibited the proliferation and survival in the breast cancer cells compared to the stem cells. Lysimachia savranii extract caused the increase of eNOS staining for oxidative stress and the TUNEL labeling for apoptosis. The further molecular techniques should be used to determine the biologic activity of Lysimachia savranii extract and its content should be investigated.
\end{abstract}

Keywords: Lysimachia savranii, breast cancer, proliferation, cytotoxicity.

Öz: Meme kanseri, giderek artan oranda kadınların yaşamları için bir tehdit haline gelmiştir. Yetersiz cerrahi işlemler ve kemoterapi tedavileri hasta yaşam kalitesini olumsuz yönde etkilemektedir. Bu nedenle, özellikle bitkisel ürünlerin kullanımı için alternatif ve destekleyici ajanlara olan talep artmıştır. Bu çalışmanın amacı, meme kanseri hücre dizinlerinde Lysimachia savranï̀nin in vitro anti-tümör aktivitesini, normal yağ doku kaynaklı mezenkimal kök hücrelerle karşılaştırarak araştırmaktur. Yağ dokusu kaynaklı mezenkimal kök hücreler, MCF-7 ve MDA-MB-231 meme kanseri hücreleri, in vitro ortamda kültüre edildi. Her bir hücre için Lysimachia savranī nin IC $_{50}$ dozlar1 MTT metodu ile belirlendi. Oksidatif stres için eNOS ile immünositokimyasal boyama yapılırken, apoptosis TUNEL metodu ile analiz edildi. Veriler H-skor ve apoptotik indeks ile gösterildi. Bitki ekstraktının, meme kanseri hücrelerinde, proliferasyon ve canlılığ1, kök hücrelere kyyasla inhibe ettiği görüldü. Lysimachia savranii ekstraktı, oksidatif stres için eNOS ve apoptoz için TUNEL boyanmasında artışa neden oldu. Lysimachia savranii ekstraktının biyolojik aktivitesini belirlemek için başka moleküler teknikler kullanılmalı ve içeriği araştırılmalıdır.

\begin{tabular}{ll}
\hline Anahtar Kelimeler: Lysimachia savranii, meme kanseri, proliferasyon, sitotoksisite. \\
\hline${ }^{*}$ Corresponding author : Iş1l AYDEMIR & e-mail : isil_aydemir@yahoo.com \\
Geliş tarihi / Received : 08.10.2019 & Kabul tarihi / Accepted: 12.11.2019 \\
\hline
\end{tabular}

\section{Introduction}

In the health area, the cancer is the second most common cause of death after cardiovascular disease. Especially in women, breast cancer is a major health problem because of its high mortality and morbidity. Therefore, intensive research is needed to treat this type of cancer (Torre et al., 
2016, DeSantis et al., 2016). With the increase in breast cancer cases in recent years, the status of metastasis negatively affects the treatment. It is reported that the risk of metastasis is higher in breast cancer, especially estrogen receptor independent. Because of metastasis, cancer treatment may be inadequate, and therefore there is a tendency to seek alternative or complementary treatment options. The herbal products are one of alternative or complementary treatment agents. In vitro and in vivo studies have shown that many chemotherapeutic agents and herbal products are used for their cytotoxic effect and antitumoregenic properties on breast cancer (Hack et al., 2015, Kim et al., 2015, Zheng et al., 2016, Tariq et al., 2017).

The reactive oxygen species (ROS) play a role in the metabolic events of the cells, but the accumulation of ROS causes cell death by oxidative stress (Trachootham et al., 2009). In the cancer treatment, the aim is to trigger cell death of tumor cells without damaging healthy cells. The apoptosis is desired because it is programmed cell death (Sumalatha et al., 2017).

Lysimachia savranii is a new species belonging to the Primulaceae family and the biological effects of this specie have not been studied. The other species of Primulaceae, such as Lysimachia capillipes, Lysimachia punctata, Lysimachia fortunei, Lysimachia parvifolia, Lysimachia nummularia and Lysimachia cletbroides have been reported to have analgesic, antibacterial, antiinflammatory and cytotoxic effects (Podolak et al., 2005, Podolak et al., 2013, He et al., 2013, Liang et al., 2013, Fei et al., 2014). In the current experiment, we aimed to define the cytotoxic effect of Lysimachia savranii extract on adipose tissue derived mesenchymal stem cells (ADSCs), MCF-7 and MDA-MB-231 breast cancer cell lines by oxidative stress and cell death.

\section{Material and Methods}

\section{Preparation of Plant Extract}

Lysimachia savranii was gathered in term of July 2013 from the Bolkar Mountains within the boundaries of Niğde province. Its taxonomic classification was made by biolog Ahmet Savran.
In the current study, the leaf parts of the plant were used for extraction. The extraction method was performed according to the previously described protocol (Atila et al., 2019). Briefly, the dried plant materials were powdered using electric blender. Twenty gram $(20.0 \mathrm{~g})$ of Lysimachia savranii powdered samples were extracted with 500 $\mathrm{ml}$ of solvents ( $95 \%$ ethanol) for $3 \mathrm{~h}$ by using Soxhlet apparatus. The extract were concentrated using a rotary evaporator at $40{ }^{\circ} \mathrm{C}$.

\section{Cell Culture}

The breast cancer cell lines MCF-7 and MDA-MB231 were purchesed from DSMZ- German Collection of Microorganisms and Cell Cultures, Germany. As control group, adipose tissue derived mesenchymal stem cells (ADSC), in a previous study (Ethics approval number: 17/09/2014/77.637.435-32, Manisa Celal Bayar University, Animal Experiments Local Ethics Committee) frozen, were used. MCF-7 and MDAMB-231 were grown in RPMI-1640 (F1213, Biochrom, Berlin Germany) containing 10\% fetal bovine serum (S0113, Biochrom, Berlin Germany), $200 \mathrm{mM} \quad$ L-glutamin, $100 \mathrm{UI} / \mathrm{ml}$ penicillin/streptomycin (A2213, Biochrom, Berlin, Germany), at $37^{\circ} \mathrm{C}$ in $5 \% \mathrm{CO}_{2}$ in a humidified atmosphere. ADSCs at passage 3 were taken from $-80^{\circ} \mathrm{C}$ and were dissolved at $37^{\circ} \mathrm{C}$. Then the cells were cultured in alpha-MEM (F0915, Biochrom, Berlin, Germany), 10\% fetal bovine serum $\mu \mathrm{g} / \mathrm{ml}$ gentamisin (A2712, Biochrom, Berlin, Germany), 100UI/ml penicillin/streptomycin (A2213, Biochrom, Berlin, Germany), $100 \mathrm{UI} / \mathrm{ml}$ amphotericin B (A2612, Biochrom, Berlin, Germany) and $200 \mathrm{mM}$ L-glutamin (K0282, Biochrom, Berlin, Germany). The medium was changed every two days.

\section{Cytotoxicity Assay}

To detect $\mathrm{IC}_{50}$ of Lysimachia savranii extract for each cells, 3-(4,5-dimethylthiazol-2-y1)-2,5diphenyltetrazolium bromide (MTT, M5655, Sigma, Steinheim, Germany) assay was performed. All cells were put into 96 -well $(2.5 \times 105$ cells/well $)$ plates and seeded for $24 \mathrm{~h}$. The cells were treated with an increasing concentration of plant extract 
in ethanol $(0,0.1,1,10,30,100 \mu \mathrm{gr} / \mathrm{ml})$ for 24 hours. Then the media containing extract was removed and $100 \mu \mathrm{L}$ of fresh medium and $10 \mu \mathrm{L}$ MTT $(5 \mathrm{mg} / \mathrm{ml}$ in distiled water) were added. After the incubation with MT'T at $37^{\circ} \mathrm{C}$ for $4 \mathrm{~h}$, media containing MTT was discharged, and 100 $\mu \mathrm{L}$ of dimethyl sulphoxide (DMSO, A3672, AppliChem, Darmstadt, Germany) was put into each well. The absorbance was measured at a wavelenght of $570 \mathrm{~nm}$ using an UV visible spectrophotometer multiplate reader (ELx800UV, BioTek). The $\mathrm{IC}_{50}$ dose of plant extract was calculated for each cell (Deliloglu-Gurhan et al., 2006).

\section{Immunocytochemistry}

The immunocytochemistry staining was performed to detect the level of oxidetive stress marker endothelial nitric oxide synthase (eNOS). Following the treatment with $\mathrm{IC}_{50}$ dose of plant extract for $24 \mathrm{~h}$, cells were fixed with $4 \%$ paraformaldehyde (1.04004, Merck, Darmstadt, Germany) in phosphate buffered saline (PBS, Invitrogen) at $+4^{\circ} \mathrm{C}$ for $30 \mathrm{~min}$ and were washed in PBS for 5 min. The cells were treated with $0.1 \%$ Triton X-100 (A4975, AppliChem, Darmstadt, Germany) at $+4^{\circ} \mathrm{C}$ for $15 \mathrm{~min}$ for permeabilization and the endogenous peroxidase activity was inhibited by 3\% hydrogen peroxide (1 08600, Merck, Darmstadt, Germany). Then primary antibody anti-eNOS (sc-654, Santa Cruz Biotechnology) was applied to the each cell at $+4^{\circ} \mathrm{C}$ overnight. For negative control, some samples were not put the primary antibody. Then the biotinylated secondary antibodies and peroxidase-conjugated streptavidin (Histostain kit, 85-9043, Zymed, Carlsbad, USA) were used. The diaminobenzidine/hydrogen peroxide (DAB, 002014, Invitrogen, CA, USA) and counterstaining was performed using Mayer's hematoxylin (800729-8350, ScyTek, UT, USA). The cell samples were mounted using aqueous media (K002, DBS, Pleasanton, USA) (Özdal-Kurt et al., 2016). Under light microscope (BX53, Olympus, Japan) camera attached (SC50, Olympus, Germany), the images of stained cells were obtained. The immunocytochemistry assay was performed triplicate. The staining was evaluated as weak $(+)$, moderate $(++)$ and strong $(+++)$ respectively, in five different microscopic areas. The cells were counted for each intensity and the respective score was calculated by the following formula H-Score $=\mathrm{Pi}$ (intensity of staining +1 ). $\mathrm{Pi}$ is the percentage of stained cells for each intensity, varying from $0 \%$ to $100 \%$. The $\mathrm{H}$-score was evaluated by at least two observers blinded to study independently (Ozbilgin et al., 2015) .

\section{TUNEL assay}

After the plant extract application, apoptotic cells were detected by terminal Transferase dUTP Nick End Labeling (TUNEL Promega G7130) method was used to detect the apoptotic cells. For fixation, $4 \%$ paraformaldehyde was used and for permeabilization, the cells were treated with $0.1 \%$ Triton X-100 for 15 min. After washing in PBS, endogenous peroxidase activity was eradicated by $3 \%$ hydrogen peroxide. After equilibration buffer process, cells were incubated with terminal deoxynucleotidyl transferase enzyme (Tdtenzyme) for $1 \mathrm{~h}$ at $37^{\circ} \mathrm{C}$. Then cells were applied with $2 \times$ SCC solution for $15 \mathrm{~min}$. The apoptotic cells were made visible by DAB staining and cells were stained with Mayer's haematoxylin for counterstaining. Cells were mounted with aqueous media. The TUNEL staining procedure was repeated three times (Tuğlu et al., 2010). The apoptotic cells were counted using light microscope (BX53, Olympus, Japan) by two blinded observer. The TUNEL positive and negative cells were counted in 10 randomly choosen areas, and the apoptotic index was revealed as: Apoptotic index $=$ (number of apoptotic cells / total number of cells) $\times 100$ (Pourheydar et al., 2016).

\section{Statistical analysis}

The results were statistically analyzed in GraphPad Software (San Diego, CA, USA) using repeatedmeasures of the ANOVA test and the data was given as mean $\pm \mathrm{SD}$ values. The differences between groups was determined by The TukeyKramer multiple comparisons test and values for $\mathrm{P}<0.05$ were defined as significant (Mete et al., 2016). 


\section{Results}

In our study, the $\mathrm{IC}_{50}$ doses of Lysimachia savranii extract determined to be $16.25 \mu \mathrm{gr} / \mathrm{ml}$ for ADSC,
$13.75 \mu \mathrm{gr} / \mathrm{ml}$ for MCF-7, and $12.5 \mu \mathrm{gr} / \mathrm{ml}$ for MDA-MB-231 by MT'T asssay. The plant extract was found to be significantly more toxic for MDAMB-231 cells (Figure 1).

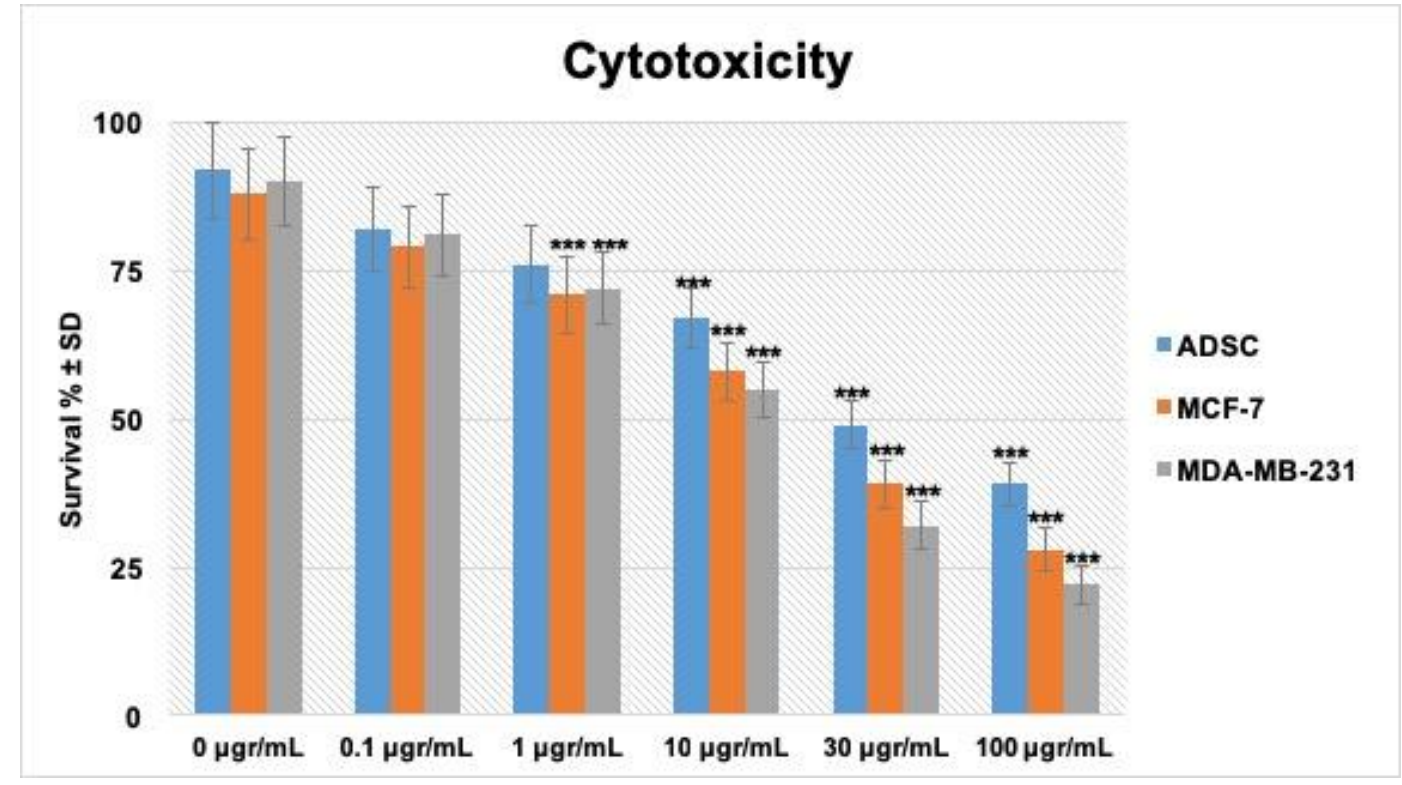

Figure 1. The cytotoxicity level of Lysimacbia savranii extract on ADSCs, MCF-7 and MDA-MB-231 breast cancer cell lines for $24 \mathrm{~h}(* * * \mathrm{P}<0.001)$.

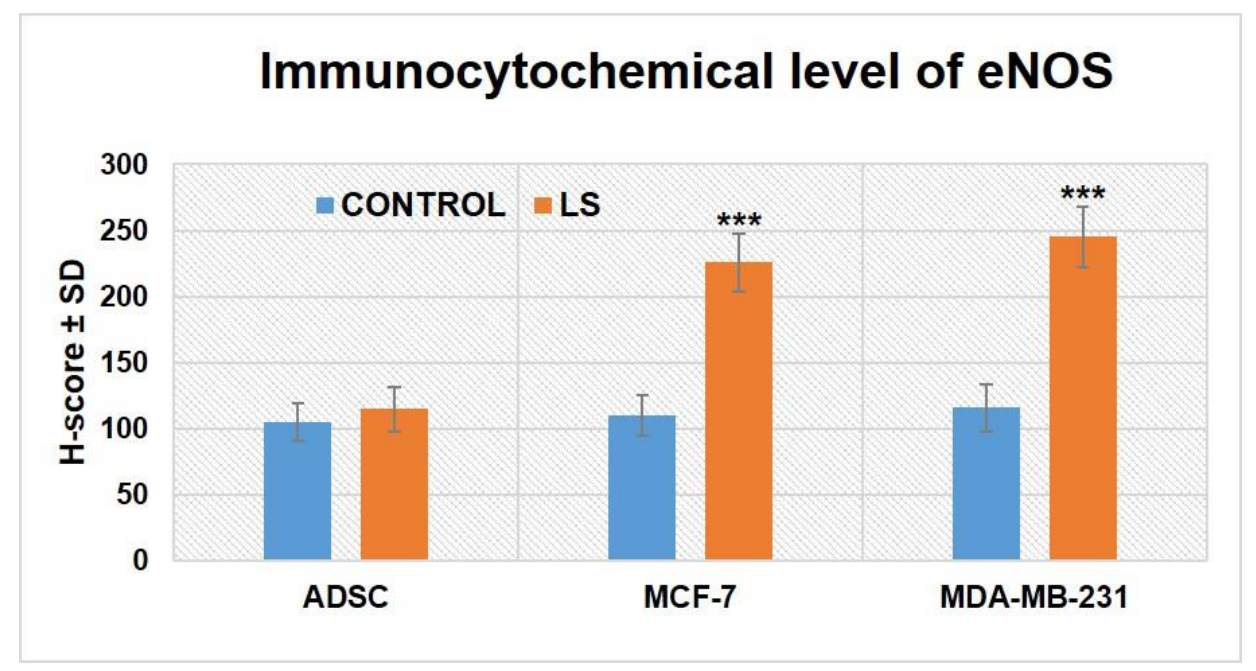

Figure 2. H-score analysis of immunocytochemical staining of eNOS in ADSCs, MCF-7 and MDA-MB231 breast cancer cells after application of Lysimacbia savranii extract $\left(\mathrm{IC}_{50}\right.$ dose $)$ for $24 \mathrm{~h}(* * * \mathrm{P}<0.001)$.

By immunocytochemistry staining, oxidative stress marker, eNOS was evaluated after $\mathrm{IC}_{50}$ doses of plant extract application by $\mathrm{H}$-score (Figure 2).

There was not a significant difference between plant extract treated ADSCs and non-treated
ADSCs $(\mathrm{P}<0.05)$. The immunoreactivity of eNOS was higher in MDA-MB-231 and MCF-7 cells than treated with plant extract ADSCs $(* * * \mathrm{P}<0.001)$. However, immunoreactivity was found to be increased in MDA-MB-231 cells $(* * * \mathrm{P}<0.001)$ than MCF-7 cells (Figure 3). 

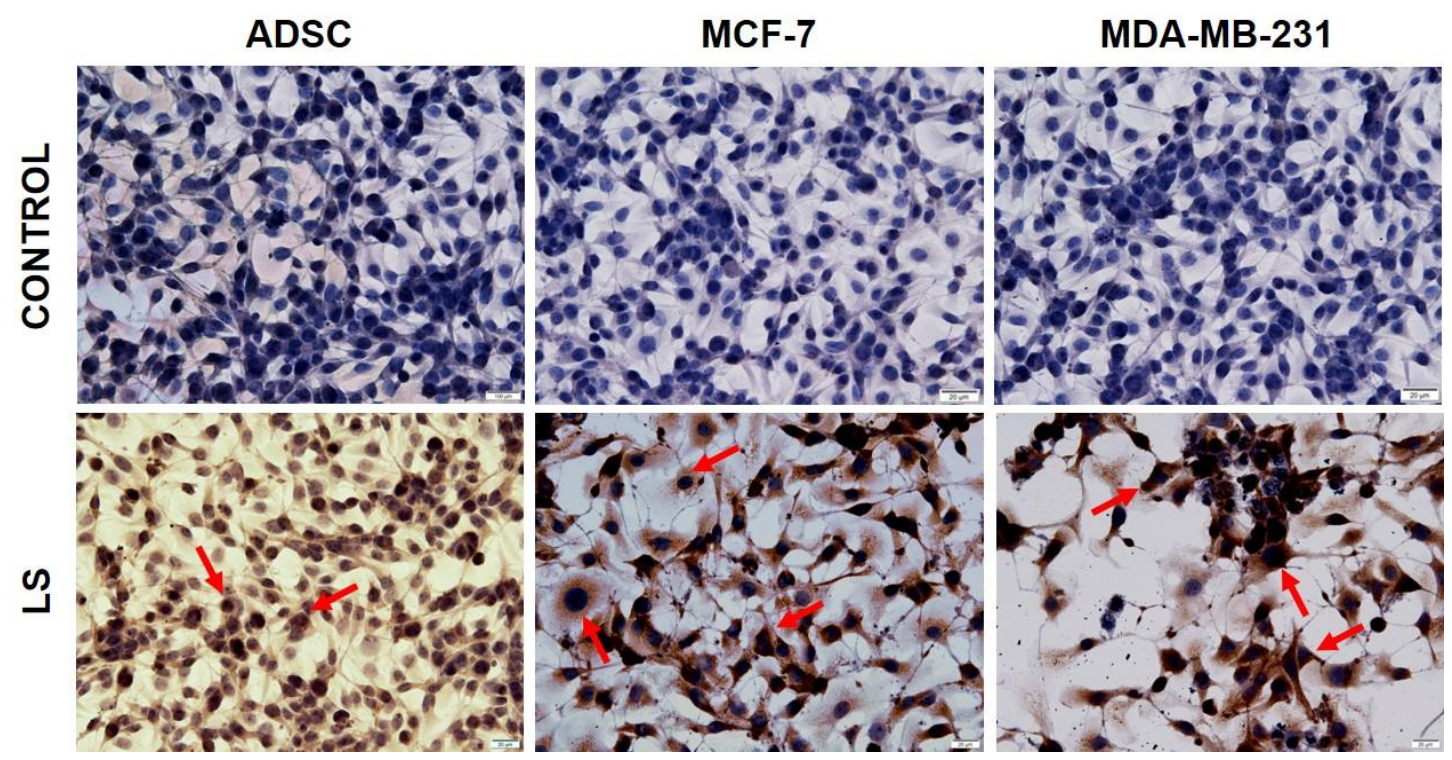

Figure 3. The distribution of immunocytochemical staining of eNOS in ADSCs, MCF-7 and MDA-MB231 breast cancer cells after application of Lysimachia savranii extract ( $\mathrm{IC}_{50}$ dose) for $24 \mathrm{~h}$. Arrows: Immunopositive cells, Scale bars: $20 \mu \mathrm{m}$.

Table 1. The apoptotic index in ADSCs, MCF-7 and MDA-MB-231 breast cancer cells after application of Lysimachia savranii extract ( $\mathrm{IC}_{50}$ dose) for $24 \mathrm{~h}$.

\begin{tabular}{ccc}
\hline CELL & CONTROL & LS \\
\hline ADSC & $9,8 \pm 1,1$ & $10,0 \pm 1,2$ \\
MCF-7 & $10,6 \pm 1,2$ & $12,0 \pm 1,5$ \\
MDA-MB-231 & $10,1 \pm 1,3$ & $13,2 \pm 1,7$
\end{tabular}

The apoptotic index were given in Table 1. In ADSCs, the increase of apoptotic cell number was not statistically significant with the application of plant extract $(\mathrm{P}<0.05)$. However, a significant increase in MDA-MB-231 cells was noted compared to non-treated cells $(* * \mathrm{P}<0.01)$ (Figure 5). Similarly, in treated MCF-7 cells, there was an increase in apoptotic cells compared to nontreated cells $(* * \mathrm{P}<0.01)$. The number of apoptotic cells was the highest in the treated MDA-MB-231 cells.

\section{Discussion}

The current study has showed that Lysimachia savranii extract has a cytotoxic effect on breast cancer cell lines MCF-7 and MDA-MB-231. The antiproliferative effect was revealed by the MT'T, immunocytochemical and TUNEL assays. The distribution of eNOS was enhanced by the application of Lysimachia savranii extract, and also apoptotic cell count was also increased. The specie we used in our study, Lysimachia savranii, have not been investigated in the previous studies, whereas the other species of Lysimachia genus were studied in vivo and in vitro experiments.

Capilliposide C agent in the saponins group isolated from Lysimachia capillipes showed no cytotoxic effect below $1 \mu \mathrm{g} / \mathrm{ml}$ in the TE- 1 and TE-2 esophageal squamous carcinoma cells. After 48 hours of administration, the $\mathrm{IC}_{50}$ dose for TE1 cells was reported to be $5.43 \pm 0.63 \mu \mathrm{M}$ and 6.64 $\pm 0.91 \mu \mathrm{M}$ for TE- 2 cells. When capilliposide $\mathrm{C}$ combined with oxaliplatin, it has been observed that antiproliferative effect is increased by synergistic effect and thus apoptosis is triggered. This effect is shown by $\mathrm{PI} 3 \mathrm{~K} / \mathrm{Akt} / \mathrm{m}$ TOR pathway which plays an important role in proliferation and metastasis, and also the increase 
of Cas3 and Bax from apoptotic markers are supported the antiproliferative effect (Shen et al., 2017).
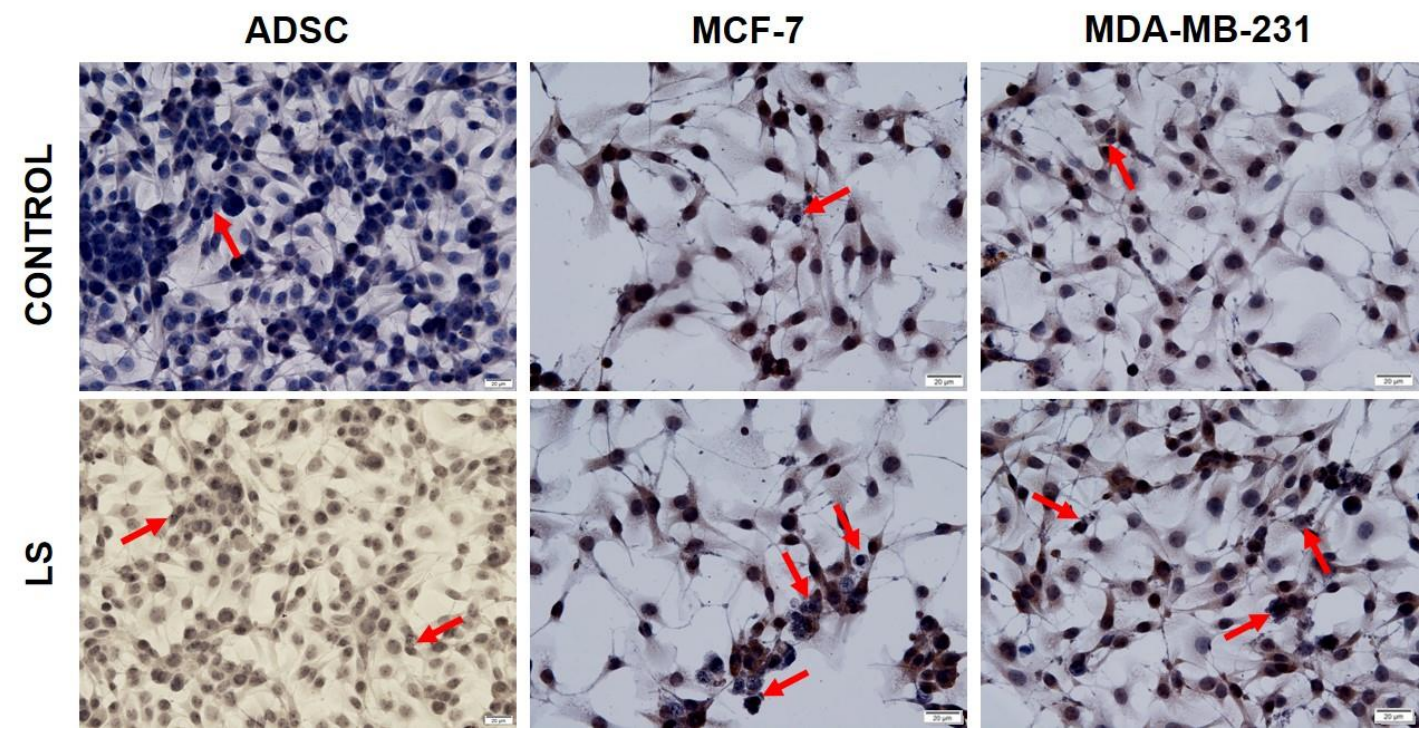

Figure 5. TUNEL staining for apoptosis in ADSCs, MCF-7 and MDA-MB-231 breast cancer cells after application of Lysimachia savranii extract ( $\mathrm{IC}_{50}$ dose) for $24 \mathrm{~h}$. Arrows: Apoptotic cells, Scale bars: $20 \mu \mathrm{m}$.

Another study with Capilliposide from Lysimachia capillipes examined its antitumourogenic effect on the lung cancer cell lines and experimental lung cancer model. It has cytotoxic effect against the lung cell lines A549, H1299 and H460 cells, and after 24 hours of treatment, the $\mathrm{IC}_{50}$ dose was calculated as $4.13 \mu \mathrm{g} / \mathrm{mL}$ for A549 cells, $3.76 \mu \mathrm{g}$ / mL for H1299 cells and $2.85 \mu \mathrm{g} / \mathrm{mL}$ for H460 cells (Fei et al., 2014). In the study with PC3 and DU145 prostate cancer cell lines, $\mathrm{IC}_{50}$ dose of Capilliposide $C$ was found to be $5.53 \pm 0.05 \mu \mathrm{Mol}$ / L for PC3 cells and $9.99 \pm 1.98 \mu \mathrm{Mol} / \mathrm{L}$ for MT3 cells. Annexin V-FITC / PI staining showed that apoptosis was enhanced with the increasing dose of Capilliposide C in PC3 cells, and this apoptotic effect was supported by the increase in Cyt-C and Bax and decrease in proCas3 with Western blot analysis (Li et al., 2014). In our study, we used the extract of Lysimacbia savranii, not a compound. Whether the toxic effect of this extract is due to the whole or a compound it contains should be investigated. Similar to the content of our study, in a previous experiment, the cytotoxic effect of Lysimachia nummularia extract on PC3, DU145 prostate cancer cells and PNT2 normal prostate cell, A-375 and BLM malignant melanoma and HSF skin fibroblast cells and U373 glioblastoma cells was reported. The $\mathrm{IC}_{50}$ dose of Lysimachia nummularia extract determined as $7.4 \pm$ $1.1 \mu \mathrm{gr} / \mathrm{mL}$ for PC3, $1.2 \pm 0.3 \mu \mathrm{gr} / \mathrm{mL}$ for DU145, and $30.0 \pm 3.2 \mu \mathrm{gr} / \mathrm{mL}$ for PNT2. While the extract showed toxic effect in prostate cancer cells at low doses, it was found that the dose increased for toxic effect in normal prostate cells. The $\mathrm{IC}_{50}$ dose for A-375 was $23.2 \pm 1.2 \mu \mathrm{gr} / \mathrm{mL}$, BLM was $17.5 \pm 1.6 \mu \mathrm{gr} / \mathrm{mL}$, for HSF was $21.3 \pm$ $1.8 \mu \mathrm{gr} / \mathrm{mL}$, and for U373 glioblastoma cells was $6.0 \pm 1.3 \mu \mathrm{gr} / \mathrm{mL}$. Furthermore Lysimacbia nummularia extract in prostate and glioblastoma cells was found to be toxic at lower doses compared to skin cancer cells (Podolak et al., 2013). In the current study, the $\mathrm{IC}_{50}$ dose of Lysimachia savranii extract was detected as $\mathbf{1 6 . 2 5}$ $\mu \mathrm{gr} / \mathrm{ml}$ for ADSCs, $13.75 \mu \mathrm{gr} / \mathrm{ml}$ for MCF-7, and $12.5 \mu \mathrm{gr} / \mathrm{ml}$ for MDA-MB-231. Besides, cytotoxic effect was supported with the increase of apoptosis and oxidative stress.

In our study, we used only the leaves of Lysimachia savranii. In previous studies, the aerial parts of 
Lysimachia genus plants were used, such as Lysimachia foenum-graecum and Lysimachia fortunei. The several compounds were isolated from aerial parts of these species, and their cytotoxic effects against to the varied cancer cell lines were reported (Dai et al., 2017, Zhang et al., 2018). Our aim is to emphasize that different parts of the plant may contain different compounds and therefore their effect on cancer cells may change.

\section{Conclusion}

In our experiment, Lysimachia savranii extract was found to have toxic effect on breast cancer cells. The toxic effect was demonstrated by MTT, immnuocytochmical staining and apoptosis. These findings should be supported by molecular techniques and further studies of in vitro and in vivo models.

Ethical approval: This article does not contain any studies with human participants or animals performed by any of the authors.

Conflict of Interest: The authors have no conflicts of interest to declare.

Financial Disclosure: The authors declared that this study has received no financial support.

\section{References}

Atila, G., Bilgili, A., Uslu, H., Erdağ, D., Özkan, O., 2019. Effects of Allium tuncelianum on hyperglycemia and oxidative stress in the kidney and liver tissues in rats with diabetes mellitus induced by streptozotocin. Ankara Üniversitesi Veteriner Fakültesi Dergisi 66, 185190.

Dai, L.M., Huang, R.Z., Zhang, B., Hua, J., Wang, H.S., Liang, D., 2017. Cytotoxic triterpenoid saponins from Lysimachia foenumgraecum. Phytochemistry 136, 165-174. doi: 10.1016/j.phytochem.2017.01.021.

Deliloglu-Gurhan, I., Tuglu, I., Vatansever, H.S., Ozdal-Kurt, F., Ekren, H., Taylan, M., Sen, B.H., 2006. The effect of osteogenic medium on the adhesion of rat bone marrow stromal cell to the hydroxyapatite. Saudi Medical Journal 27(3), 305-11.
DeSantis, C.E., Fedewa, S.A., Goding Sauer, A., Kramer, J.L., Smith, R.A., Jemal, A., 2016. Breast cancer statistics, 2015: Convergence of incidence rates between black and white women. CA: A Cancer Journal for Clinicians 66(1), 31-42. doi: $10.3322 /$ caac. 21320 .

Fei, Z.H., Wu, K., Chen, Y.L., Wang, B., Zhang, S.R., Ma, S.L., 2014. Capilliposide Isolated from Lysimachia capillipes Hemsl. Induces ROS Generation, Cell Cycle Arrest, and Apoptosis in Human Nonsmall Cell Lung Cancer Cell Lines. Evidence-Based Complementary and Alternative Medicine 497456. doi: 10.1155/2014/497456.

Hack, C.C., Voiß, P., Lange, S., Paul, A.E., Conrad, S., Dobos, G.J., Beckmann, M.W., Kümmel, S., 2015. Local and Systemic Therapies for Breast Cancer Patients: Reducing Short-term Symptoms with the Methods of Integrative Medicine. Geburtshilfe Frauenheilkd 75(7), 675682.

He, Z., Liang, F., Lu, J., Pan, Y., 2013. Cytotoxic triterpenoids from Lysimachia parvifolia. European Journal of Medicinal Chemistry 67, 390-7. doi: 10.1016/j.ejmech.2013.06.043.

Kim, W., Lee, W.B., Lee, J.W., Min, B.I., Baek, S.K., Lee, H.S., Cho, S.H., 2015. Traditional herbal medicine as adjunctive therapy for breast cancer: A systematic review. Complementary Therapies in Medicine 23(4), 62632. doi: 10.1016/j.ctim.2015.03.011.

Mete, M., Aydemir, I., Ünsal, Ü.Ü., Duransoy, Y.K., Tuğlu, M.I.,, Selçuki, M., 2016. Neuroprotective effects of bone marrow-derived mesenchymal stem cells and conditioned medium in mechanically injured neuroblastoma cells. Turkish Journal of Medical Sciences 46, 19001907,

Özdal-Kurt, F., Tuğlu, I., Vatansever, H.S., Tong, S., Şen, B.H., Deliloğlu-Gürhan, S.I., 2016. The effect of different implant biomaterials on the behavior of canine bone marrow stromal cells during their differentiation into osteoblasts. Biotechnic and Histochemistry 91(6), 412-22. doi: 10.1080/10520295.2016.1183819.

Ozbilgin, K., Karaca, F., Turan, A., Köse, C., Vatansever, S., Ozcakir, T., 2015. The higher heparin-binding epidermal growth factor (HBEGF) in missed abortion. Taiwanese Journal of 
Obstetrics and Gynecology 54(1), 13-8. doi: 10.1016/j.tjog.2013.08.011.

Li, R., Zhang, L., Zhang, L., Chen, D., Tian, J., Cao, L., Zhang, L., 2014. Capilliposide C derived from Lysimachia capillipes Hemsl inhibits growth of human prostate cancer PC3 cells by targeting caspase and MAPK pathways. International Urology and Nephrology 46(7), 1335-44. doi: 10.1007/s11255-013-0641-6.

Liang, D., Hao, Z.Y., Liu, Y.F., Luo, H., Wang, Y., Zhang, C.L., Zhang, Q.J., Chen, R.Y., Yu, D.Q., 2013. Bioactive carboxylic acids from Lysimachia clethroides. Journal of Asian Natural Products Research 15(1), 59-66. doi: 10.1080/10286020.2012.745855.

Podolak, I., Koczurkiewicz, P., Michalik, M., Galanty, A., Zajdel, P., Janeczko, Z., 2013. A new cytotoxic triterpene saponin from Lysimachia nummularia L. Carbohydrate Research 375, 16-20. doi: 10.1016/j.carres.2013.04.005.

Podolak, I., Galanty, A., Janeczko, Z., 2005. Cytotoxic activity of embelin from Lysimachia punctata. Fitoterapia 76(3-4), 333-5.

Pourheydar, B., Soleimani Asl, S., Azimzadeh, M., Rezaei Moghadam, A., Marzban, A., Mehdizadeh, M., 2016. Neuroprotective Effects of Bone Marrow Mesenchymal Stem Cells on Bilateral Common Carotid Arteries Occlusion Model of Cerebral Ischemia in Rat. Behavioural Neurology 2016, 2964712.

Shen, Z., Xu, L., Li, J., Zhang, N., 2017. Capilliposide C Sensitizes Esophageal Squamous Carcinoma Cells to Oxaliplatin by Inducing Apoptosis Through the PI3K/Akt/mTOR Pathway. Medical Science Monitor 23, 2096-2103.

Sumalatha, K., Gowda, M., 2017. Meenakshisundaram S. ROS-mediated induction of apoptosis by benzoquinone embelin in human colon adenocarcinoma cells HT-29. Journal of Complementary and Integrative Medicine 14(2), pii:/j/jcim.2017.14.issue-2/jcim-2016-0131/jcim2016-0131.xml. doi:10.1515/jcim-2016-0131.

Tariq, A., Sadia, S., Pan, K., Ullah, I., Mussarat, S., Sun, F., Abiodun, O.O., Batbaatar, A., Li, Z., Song, D., Xiong, Q., Ullah, R., Khan, S., Basnet, B.B., Kumar, B., Islam, R., Adnan, M., 2017. A systematic review on ethnomedicines of anti-cancer plants. Phytotherapy Research 31(2), 202-264. doi: 10.1002/ptr.5751.

Torre, L.A., Siegel, R.L., Ward, E.M., Jemal, A., 2016. Global Cancer Incidence and Mortality Rates and Trends--An Update. Cancer Epidemiology, Biomarkers and Prevention 25(1), 16-27. doi: 10.1158/1055-9965.

Tuğlu, İ., Özdal-Kurt, F., Koca, H., Sarac, A., Barut, T., Kazanç, A., 2010. The contribution of differentiated bone marrow stromal stem celloaded biomaterial to treatment in critical size defect model in rats. Kafkas Universitesi Veteriner Fakültesi Dergisi 16 (5), 783-792. DOI:10.9775/kvfd.2010.1582.

Trachootham, D., Alexandre, J., Huang, P., 2009. Targeting cancer cells by ROS-mediated mechanisms: a radical therapeutic approach? Natural Reviews Drug Discovery 8(7), 579-91. doi: $10.1038 / \operatorname{nrd} 2803$.

Zhang, S.L., Yang, Z.N., He, C., Liao, H.B., Wang, H.S., Chen, Z.F., Liang, D., 2018. Oleanane-type triterpenoid saponins from Lysimachia fortunei Maxim. Phytochemistry 147, 140-146. doi: 10.1016/j.phytochem.2017.12.022.

Zheng, J., Zhou, Y., Li, Y., Xu, D.P., Li, S., Li, H.B., 2016. Spices for Prevention and Treatment of Cancers. Nutrients 8(8), pii: E495. doi: 10.3390/nu8080495. 